\title{
An evolutionary approach to mating behaviour and drone copulatory organs in Apis
}

\author{
N Koeniger, G Koeniger \\ Universität Frankfurt aM, Institut für Bienenkunde (Polytechnische Gesellschaft), \\ Fachbereich Biologie der JW Goethe- Karl-von-Frisch-Weg 2, 637 Oberursel 1, Germanry
}

(Received 27 September 1991; accepted 2 December 1991)

\begin{abstract}
Summary - Copulation in free flight seems to be a common character of all Apis species. Analysis of mating behaviour in $A$ mellifera revealed the typical behavioural sequence of mating on a substrate in Apoidea. The connection between the queen and the paralyzed drone is mainly achieved by the endophallus. By special adhesive organs on the hind legs of the drone, $A$ dorsata has developed an additional means of attachment to the queen. $A$ andreniformis and $A$ florea drones have $r \theta-$ duced the mass of mucus and seem to depend mainly on the hind legs for the copulatory connection to the queen. The $A$ florea endophallus, freed from its mechanical function, can place its tip in the optimal position: sperm is transferred directly into the spermaduct rather than into the oviducts. The opposite polarity - an evolution from substrate mating to an $A$ florea type and then to an $A$ cerana and $A$ mellifera type lacks of any functional support.
\end{abstract}

evolution / mating behaviour / copulation / Apis

Recent publications on Apis taxonomy agree on the relation between the species. But the discussion on the polarity of the evolution within the genus is still controversial. We want to focus in this paper on mating behaviour. An 'out group comparison' on several features of mating behaviour will be used for gaining insight into the polarity of the evolution within the genus Apis.

In many Apoidea mate locations are diverse. Mating occurs at emergence sites, oviposition sites, feeding places and flowers or at places solely or primarily visited for mating (Anzenberger, 1977; Alcock et al, 1978; Eickwort and Ginsburg, 1980).
Many Bombini copulate at speciesspecific locations where the queen is attracted by drone pheromones (Haas, 1949; Michener, 1974). In Meliponini males congregate near nests with virgin queens, either resting or flying in the vicinity, where they compete for copulation (Kerr et al, 1962; Da Silva et al, 1972; Engels 1987, 1988). In Melipona quadrifasciata the queen undertakes a mating flight (da Silva et al, 1972), but do not necessarily mate during flight, since Camargo (1972) obtained mating in small boxes. Other stingless bees also copulate in "mating boxes" (Engels and Engels, 1988). 
In contrast to mating locations, copulation behaviour generally is rather uniform. The male mounts the female from behind the dorsum. He holds the female's abdomen by the grip of his legs and inserts the penis into the bursa copulatrix. The male genital organ gains hold. The male loses the grip of his legs and swings back. In this position the female is resting on a substrate and the male hangs his ventral side upward behind her. The connection of the couple depends on the penis and its accessory structures which are anchored in the genital orifice or the vagina. The separation of the couple is done in various ways which show species specific sequence. Often it is initiated by the female.

In Bombus, males "usually land upon the thorax of a female, knocking her down to the ground. The male then climbs on her back and attempts to copulate, grasping her body with his legs. If and when coition is achieved the queen's sting is protruding and the male, presumably to avoid the sting, releases his hold and falls backwards, the pair remaining attached only in the genital region" (Alford, 1975).

In some Xylocopini, the male mounts the flying female for about 15 to 45 s during which time the pair hovers, or flies a short distance and land on a leaf or a twig (Vinson and Frankie, 1990). In these cases the male is still able to fly during coition.

In the genus Apis copulation seems to happen high up in the air. Drones generally do not react to queens which are placed on the ground. Though many attempts were undertaken, successful mating in confinements was never obtained (Harbo, 1971). In $A$ mellifera experiments with dummies and tethered queens (Gary 1963; Koeniger et al, 1979; Koeniger 1984) which were lifted high in the air a natural drone congregation areas resulted in copulation of natural free flying drones. Similar results were obtained with $A$ cera- na by Ruttner (1973) and more recently by Punchihewa et al (1990). In other Apis species (A koschevnikovi, $A$ dorsata, $A$ andreniformis, $A$ florea), drones leave the colony at species specific hours for mating flights (Koeniger and Wijayagunesekara, 1976; Koeniger et al, 1988).

While direct observations and experimental evidence on mating is still marginal, the anatomy of all Apis drones, their sex specific sensory organs, the structure of the endophallus and other characteristics strongly support the conclusion that mating during flight is a common character of all honey bees. So, sensu Hennig (1969) an aerial copulation must be considered as 'autapomorph' for the genus Apis.

The physical conditions for copulating in the air differ, compared to mating on some substrate, and significant morphological adaptations are required. In this paper we discuss mainly the question of how the connection between the mating couple is achieved and how it varies among the Apis species.

In $A$ mellifera the behavioural sequence of the copulation between a tethered queen and free flying drones was documented by film several years ago (Gary, 1969; Koeniger, 1981, 1988). Though filmed high in the air, the mating behaviour showed surprisingly little deviations from the typical apoidean sequence: The flying drone mounted the queen from behind. After making contact with his front and middle legs on the female's abdominal tergites, the metatarsi of the male's hind legs cling to the ventral side of the queens abdomen. When the queen opens her sting chamber, he inserts the endophallus. With the eversion of the endophallus the wings of the drone stop moving. He swings back and remains in this position for a short moment. After the full eversion of the endophallus he separates from the queen and falls paralysed to the ground where he 
dies. The whole copulation period takes less than $5 \mathrm{sec}$.

Anatomical dissections of deep frozen pairs in copulation (Koeniger, 1984, 1986) allowed some functional conclusions. After eversion of only half of the endophallus, the drone swings backwards, his hind legs still clinging to the ventral side of the queens abdomen (Koeniger et al, 1979). By the previous contraction of the abdominal muscles the drone had pressed mucus into the membranous endophallus which very firmly fills the sting chamber. The cornua with their sticky secretion increase the strength of the attachment. Thus the endophallus is anchored in the queen by its turgor like "a cork in a bottle". In this stage the queen continues to fly and for a moment carries the motionless drone. Then the queen contracts the bursa and presses the endophallus which results in sperm transfer into the median oviduct. At the same time the eversion of the endophallus progresses and leads to the separation of the couple. The drone falls to the ground, leaving mucus and the cornual secretions as mating sign in the queen's sting chamber. The mating sign at the tip of the flying queen's abdomen enhances the attraction of further drones and facilitates subsequent copulations (Koeniger 1986, 1990).

On average, the $A$ mellifera queen is mated by 8 drones during one mating flight. Queens may undertake a second flight so, on average, a queen is mated by 12 drones (Woyke 1960, Adams et al, 1977, Cornuet et al, 1986). Upon returning to the colony the queen's oviducts are filled with about 120 million spermatozoa. About 6 million of these eventually reach the spermatheca by passing through the narrow ductus spermaticus, while about $95 \%$ of the spermatozoa from the oviducts are expelled via the vagina.

In $A$ mellifera it is mainly the large membranous endophallus which connects the drone to the queen. Filled under high muscular pressure with mucus it seems to guarantee a sufficiently strong connection between the flying queen and the motionless drone until the sperm transfer is completed. The cornual secretion which has a greasy and sticky quality may first contribute to strengthen the attachment and later smooth the process of the eversion which leads to the separation. The endophallus of $A$ cerana and $A$ koschevnikovi drones seem to function in a similar way. The functional parts do not show significant deviations. Species-specific characteristics occur mainly in the form of the hairy patches and the dorsal cornua (Koeniger et al, 1991).

In comparison to the previously discussed species, $A$ dorsata has a more elongated endophallus with four long curled cornua. The elongation is mainly caused by the extended cervix. The mucus glands are relatively small. In particular the drones of this species have broadened metatarsi at the hind legs which show conspicuous feathered hairs. This 'adhesive organ' (Ruttner 1975, 1988) on the drone's metatarsus is believed to reinforce the attachment to the queen during copulation. Though the mating behaviour of this species is yet unknown, morphologically $A$ dorsata represents another development. In the cavity-nesting species the organ of attachment was primarily the endophallus, here the hind legs with its specific hairy structures on the metatarsus serve this function.

The drone of $A$ florea has a forceps-like appendix at the metatarsus of the hind leg. With these "thumbs" the drone locks himself to the hindlegs of the queen (Ruttner 1988), supported again by the sticky cornua pressed into the sting chamber. Thus the pair stays connected until the queen turns her leg in a way that the drone is released. Since the connection in the $A$ flor- 
ea couple is made by legs there is no further need of mucus - the mucus glands in $A$ florea drones are rudimentary. Another consequence of this new copulatory attachment is that the bulb is no longer fixed in a firm plug of mucus within the bursa copulatrix. Drones can compete to deposit the spermatozoa at more 'profitable' locations where the spermatozoa have a higher probability to reach the spermatheca. At the end of this development drones would press the tip of the endophallus to the opening of the ductus spermaticus and transfer the spermatozoa directly into the spermatheca. This type of mating was observed in $A$ florea recently (Koeniger et al, 1989).

$A$ andreniformis has an endophallus of the $A$ florea type with its own species specific characteristics (Wongsiri et al, 1990). The metatarsus of the drone's hind legs has an appendix a little shorter than A florea's, mucus glands are small and the endophallus ends in a tip. So, $A$ andreniformis drones probably also transfer their sperm directly into the spermatheca.

\section{DISCUSSION}

There seems to be general agreement among recent authors on Apis taxonomy that there are mainly three types or closely related groups:

1. The cavity-nesting type with its multiple combs ( $A$ mellifera, $A$ cerana and $A$ koschevnikovi).

2. The A dorsata complex (with several distinct forms like $A d$ laboriosa and $A d$ binghami). These bees nest in the open and build one single comb under a branch or other more or less horizontal support.

3. The small free nesting type with one comb around a branch or an edge of a rock ( $A$ florea and $A$ andreniformis).
But the discussion on the polarity of the evolution within the genus is still controversial. Based on his fundamental discoveries of the dance behaviour of the Asian honeybees, Lindauer (1956) considered $A$ florea dance as an ancestral type which evolved via an $A$ dorsata dance type to the $A$ mellifera/A cerana dance which can be performed within the darkness of the nest. Koeniger (1976) argued that dance communication depends on nesting site. Since the basal forms of Apoidea are nesting in cavities he suggested that the ancestral Apis should be a cavity-nesting form. Further, (applying Occam's razor) it is unlikely that ancestors of the cavity-nesting species of today passed through a phase of open nesting and then returned into a cavity again. Instead the free nesting forms might have branched away and evolved their dance using other information for their communication system which became available when bees nested outside. With more recent research on the Asian species, several such fundamental differences in dance communication were discovered (Koeniger and Koeniger, 1980; Koeniger et al, 1982; Dyer, 1985, 1990).

Alexander (1991) examined 19 characters of the adult morphology including 11 structures from the drone. Two characters refer to the behaviour of workers. In his cladistic analysis $A$ florea/A andreniformis type gained a basal position while the cavity-nesting types were categorized as more derived. Surprisingly, in the same paper Alexander (1991) stated 'The drones of Apis florea and Apis andreniformis have more unquestionable derived features of external morphology than any other species in the genus. That is, in overall external appearance, the drones of ancestral Apis may have more looked like mellifera than florea.'

There are some more features of the drone which we want to introduce into our evolutionary arguments: 


\section{Sperm numbers:}

Sperm numbers of males in Apinae are known only from few species (besides Apis). In drones of $M$ quadrifasciata a number of 1 to 1,2 million were found (Kerr et al, 1962). Drones of Bombus terrestris and $B$ lapidarius have 0,75 million (Röseler 1973).

In $A$ cerana drones produce about 1.2 million spermatozoa, in $A$ dorsata 2,46 million (Koeniger et al, 1990). Within the Apis species two extremes occur. While an Apis mellifera drone produces between 10 and 12 million (Woyke 1960, 1975, Rinderer et al, 1985), $A$ andreniformis drones produce only 0,13 million. $A$ florea too has only a small amount with 0,43 million (Koeniger et al, 1990). Though the number of non Apis is limited, $A$ cerana seems to be nearest to the ancestral condition.

\section{Occurence of mating signs:}

Mating signs, left by males in the queen, were reported in Scaptotrigona postica (Engels and Engels, 1988) and other Meliponinae (Kerr et al, 1962). It is described in $M$ quadrifasciata as 'whitish pieces including the thread like remains of the male genitalia' (da Silva et al, 1972, p. 128). The white colour and the description points to mucus being a prominent component of the Melipona mating sign. Further, its removal by scrubbing the tip of the abdomen on the surface of cells is similar in $A$ mellifera and $M$ quadrifasciata.

A mating sign occurs in the cavitynesting forms ( $A$ cerana and $A$ mellifera). The male accessory glands in $A$ florea and $A$ andreniformis are reduced and do not produce enough mucus for a mating sign.

3. After copulatory transfer of spermatozoa:

In $M$ quadrifasciata spermatozoa are deposited in the queen's oviducts. After copulation the spermatozoa leave the oviducts and enter into the spermatheca (Kerr et al, 1962). In the cavity-nesting species, $A$ cerana and $A$ mellifera a similar after copulatory transfer of spermatozoa is found.

We consider $A$ cerana (or $A$ koschevnikovi?) nearest to the ancestral Apis type. Like substrate mating Apoidea, the connection of the couple is based mainly on the genitalia, the sperm number is 1,2 million and the drone leaves a mating sign. Still within this level the $A$ mellifera drone shows special adaptations by high sperm numbers. A derived type is presented by the $A$ dorsata complex where the legs participate in holding the copulatory pair together. But the specific structure of the adhesive organ and the elongated cervix of $A$ dorsata suggest that this step might have occurred independently of the $A$ florea, $A$ andreniformis mating type. The metatarsal organs in small free-nesting bees present the main means of attaching the drone to the queen. So the $A$ florea endophallus freed from its mechanical function, has moved its tip (elongated bulbus) into the optimal position. The comparison of the relative heavy weight of the mucus of the cavity-nesting drones (Rinderer et al, 1985) to light weight of metatarsal organs of the small free nesting bees results in considerable energy saving during drone's mating flight.

Based on mating behaviour and male copulatory organ morphology, the opposite polarity, that of an evolution from a substrate mating via an $A$ florea or an $A$ dorsata type to an $A$ cerana and $A$ mellifera type, is unsubstantiated.

Recent publications on Apis phylogeny (Alexander, 1991; Garnery et al, 1991) present cladograms which are consistent with the 'scenario' discussed here. Our results on the functional aspect of the copulatory attachment place the cavity-nesting forms nearest to the ancestral condition. Ruttner (1988) stated 'Surprisingly the 
most specialized organ (endophallus) is found in $A$ dorsata the most 'primitive' species'. In a similar way, Alexander (1991) 'gives' $A$ florea the basal phylogenetic position within the genus Apis though he states that the $A$ florea drone has more derived characters than the drones of the other species.

The Western honey bee Apis mellifera is one of the best researched eusocial insects. Its complexity and astonishing capabilities have gained it a 'unique' position within the animal kingdom. The recent significant increase in research on the Asian honey bee species has challenged the traditionally 'mellifera-centered' view of honey bee research. Undoubtedly, the increasing knowledge of the Eastern species will result in a more balanced view of the genus Apis.

\section{Résumé - Approche évolutive du com- portement d'accouplement et des orga- nes mâles de copulation au sein du} genre Apis. Les publications récentes sur la systématique du genre Apis s'accordent sur les relations de parenté entre les espèces. Mais le sens dans lequel s'est faite l'évolution est toujours sujet à controverse. On essaie d'introduire de nouveaux arguments dans la discussion par la comparaison "hors groupe" des caractéristiques du comportement d'accouplement.

Tandis que les sites d'accouplement sont variés chez les apoïdes, le comportement de copulation est généralement assez uniforme. Le mâle chevauche la femelle par l'arrière. Après avoir inséré son pénis et les paramères génitaux le mâle lâche prise, se renverse en arrière et reste immobile, pendu à la femelle. L'union du couple est réalisée par les genitalia mâles. La copulation a lieu en général par terre ou sur un autre support.
Chez $A$ mellifera et $A$ cerana la copulation a lieu par contre en plein vol et cela semble valable pour toutes les espèces d'Apis. L'union de la reine et du mâle en vol nécessite des adaptations morphologiques. Nous nous sommes intéressés à la façon dont cette union était assurée et à ses variations entre les diverses espèces d'Apis.

L'enregistrement cinématographique du comportement de copulation entre une reine attachée et des mâles volant librement chez $A$ mellifera montre les séquences typiques des apoïdes: après éversion d'une partie de l'endophallus, le mâle reste pendu à la reine. L'union du couple n'est assurée que par la turgescence de l'endophallus, rempli du mucus des glandes accessoires mâles, et par les cornules et leur sécrétion collante. La reine déclenche la séparation en exerçant une pression sur l'endophallus. II en résulte un transfert du sperme dans les oviductes et l'éversion totale de l'endophallus. Après la séparation le mâle tombe à terre et meurt, laissant dans la reine comme signe de fécondation le mucus et la sécrétion des cornules. Le mâle suivant enlève au cours de la copulation le signe de fécondation du prédécesseur grâce à une aire pileuse située sur l'endophallus. Chez $A$ mellifera c'est principalement l'endophallus qui unit le mâle à la reine. Les endophallus d'A cerana et d' $A$ koschevnikovi ont la même structure et semblent fonctionner comme chez $A$ mellifera.

A dorsata possède un endophallus plus allongé au niveau du cervix et des glandes à mucus relativement plus petites que chez les espèces qui nidifient dans des cavités. Les métatarses des pattes postérieures des mâles sont plus larges et possèdent un organe adhésif (aire pileuse) qui aide à maintenir le couple pendant la copulation. 
Le développement de l'organe adhésif du métatarse est encore plus marqué chez $A$ florea et $A$ andreniformis, qui ont un appendice en forme de pince. À l'aide de ces "pouces" le mâle s'agrippe lui-même aux pattes postérieures de la reine. Le mécanisme d'attachement à la reine s'est déplacé de l'endophallus vers des organes supplémentaires situés sur les pattes postérieures, ce qui a réduit grandement les besoins en mucus. En outre, la forme de l'endophallus s'est modifiée de façon à ce que les spermatozoïdes puissent être déposés à l'entrée du canal de la spermathèque, ce qui entraîne son remplissage direct.

Trois autres arguments issus de la biologie de l'accouplement indiquent le sens dans lequel s'est faite, selon nous, l'évolution: 1) Le nombre de spermatozoïdes chez les mâles des autres apoïdes est d'environ 1 million. Les mâles d'A cerana en produisent 1,2 million, ceux d'A dorsata 2,3. Au sein du genre Apis on trouve les 2 extrêmes: $A$ mellifera en produit entre 10 et 12 millions, $A$ andreniformis et $A$ florea moins d'un demi-million. 2) Le signe de fécondation est présent non seulement chez $A$ cerana et $A$ mellifera mais aussi chez les Meliponinae. Il est absent chez $A$ florea. 3 ) Au cours de la copulation chez $M$ quadrifasciata les spermatozoïdes sont injectés dans les oviductes de la reine d'où ils pénètrent dans la spermathèque.

Nous considérons $A$ cerana (ou $A$ koschevnikovi?) comme l'espèce la plus proche du type ancestral d'Apis. Comme chez les apoïdes s'accouplant sur un support, l'union du couple repose sur les genitalia. À ce niveau, les mâles d' $A$ mellifera montrent des adaptations particulières en produisant une grande quantité de spermatozoïdes. En développant des organes spéciaux sur les pattes antérieures pour attacher le mâle à la reine, $A$ andreniformis et $A$ florea ont réduit la quantité de mucus.
L'endophallus d'A florea, libéré de sa fonction mécanique, peut placer son extrêmité dans la position optimale. Le comportement d'accouplement et la morphologie des organes mâles de copulation ne justifient pas l'évolution en sens opposé, qui part de l'accouplement sur un support via un type $A$ florea et $A$ dorsata pour arriver à un type $A$ cerana et $A$ mellifera.

Apis / évolution / comportement d'accouplement / copulation

Zusammenfassung - Evolution und 'Leserichtung' innerhalb der Gattung Apis am Beispiel des Paarungsverhaltens und der männlichen Begattungsorgane. In neueren Publikationen über die Taxonomie von Apis besteht Einigkeit über die Verwandtschaftsverhältnisse innerhalb der Arten. Aber die Leserichtung ist immer noch strittig. Mit einem "outgroup" Vergleich einiger Grundzüge des Paarungsverhaltens soll hier versucht werden, neue Argumente in die Diskussion einzuführen.

Der Ablauf der Kopulation bei Apoidea ist recht einheitlich. Die Männchen steigen von hinten auf das Weibchen auf. Nach der Einführung des Begattungsorgans lösen sich häufig die Beine von dem Weibchen, das Männchen schwingt nach hinten und hängt dann bewegungslos am Weibchen. Die Verbindung des Paares wird durch den Penis und akzessorischen Strukturen des Genitalapparates aufrecht erhalten. Die Kopulation findet in der Regel am Boden oder auf einem anderen Substrat statt.

Bei $A$ mellifera und $A$ cerana ist dagegen eine Kopulation in der Luft, im freien Flug nachgewiesen. Verschiedene indirekte Hinweise sprechen dafür, daß auch bei den anderen Apis-Arten eine Paarung in der Luft praktiziert wird. Die Verbindung von Königin und Drohn im freien Flug er- 
fordert spezielle Anpassungen. Welche Unterschiede gibt es dabei zwischen den Honigbienen Arten?

Filmaufnahmen von der Kopulation bei A mellifera zeigen die typische Sequenz der Apoidea: Nach der Eversion eines Teils des Endophallus hängt der Drohn nun bewegungslos an der fliegenden Königin. Die Verbindung des Paares erfolgt nur über den Turgor des Endophallus, der zusätzlich noch mit Mucus aus den männlichen Anhangsdrüsen und durch die Cornua mit ihrem klebrigen Sekret gefestigt wird. Die Trennung des Paares wird durch die Königin eingeleitet, die den Endophallus zusammenpreßt. Dabei wird Sperma in die Ovidukte übertragen. Nach vollendeter Eversion des Endophallus fällt der Drohn zu Boden und stirbt. Er hat Mucus, Chitinspangen und Cornualsekret als Begattungszeichen in der Königin hinterlassen. Der nächste Drohn entfernt während der Kopulation das Begattungszeichen seines Vorgängers mit einem speziellen Haarpolster des Endophallus.

Bei $A$ mellifera ist es vor allem der Endophallus, der - wie der Korken in einer Flasche - die Verbindung des Paares aufrecht erhält. $\mathrm{Da}$ die Endophalli von $A$ cerana und $A$ koschevnikovi sehr ähnlich gebaut sind und über entsprechend große Mucusdrüsen verfügen, nehmen wir für diese beiden Arten eine kopulatorische Verbindung des oa 'Mellifera'-Typs an.

Der Endophallus des Drohns von A dorsata hat eine verlängerte Cervix und relativ kleinere Mucusdrüsen im Vergleich zu den höhlenbrütenden Arten. Die Metatarsi der Hinterbeine besitzen ein spezielles Haarpolster. Dieses tarsale Haftorgan unterstützt den Zusammenhalt des Paares während der Kopula.

Bei $A$ florea ist die Verbindung des Paares über die Hinterbeine effektiver gestaltet. Die Drohnen haben nicht nur spe- zielle Hafthaare, der Metatarsus ist zu einem "Klammerhaftapparat" (Ruttner, 1975) umgestaltet, bestehend aus "Hand und Daumen", mit denen sich der Drohn an die Hinterbeine der Königin anklammert. Mit der Verlagerung der Haltefunktion vom Endophallus auf die Beine gehen Veränderugen im Bau des Endophallus einher. Der Bulbus ist lang und schmal und kann die Spermien direkt an die Öffnung des Ductus spermaticus plazieren. Das ergibt dann eine direkte Füilung der Spermatheka. Es wird kaum noch Mucus produziert, es gibt kein Begattungszeichen.

Die Verankerung des Paares in Kopula durch den Endophallus ist ursprünglich, die funktionelle Verschiebung auf die Beine ist abgeleitet.

Es gibt drei weitere Argumente aus der Paarungsbiologie, die die Entwicklungsrichtung der Evolution aufzeigen.

1. Die Spermazahlen von Hummeln und von Meliponinen betragen etwa 1 Million. Diesen Werten kommt $A$ cerana mit 1,2 Millionen Spermatozoen und $A$ dorsata mit 2,3 Millionen am nächsten. Innerhalb von Apis treten zwei Extreme auf, $A$ andreniformis und $A$ florea haben weniger als $1 / 2$ Million, $A$ mellifera zwischen 10 und 12 Millionen.

2. Begattungszeichen gibt es nicht nur bei $A$ mellifera und $A$ cerana sondern auch bei Meliponinen.

3. Auch bei Melipona wird das Sperma zunächst in den Eileiter übertragen und wandert später in die Spermatheka.

Zusammenfassend meinen wir, daß der Drohn von A cerana (oder $A$ koschevnikovi?) dem Basistyp der Honigbiene am meisten entspricht. Wie bei der typischen Paarung der Apoidea auf einem Substrat wird hier die Verbindung des Paares von den Genitalien aufrecht erhalten. Die hohe Spermazahl von $A$ mellifera weist auf eine Spezialentwicklung des Paarungsverhaltens dieser Art hin. 
Durch die Entwicklung spezieller Haftorgane an den Hinterbeinen wird die Funktion des Endophallus als die Verbindung des Paares während der Luftkopulation geringer. Die spezielle Ausgestaltung des $A$ dorsata Endophallus und die Struktur der Metatarsi können als eigene Enwicklung gedeutet werden. Die Menge an Mucus ist vor allem bei $A$ florea und $A$ andreniformis reduziert. Die Endophalli (Bulbus) von diesen beiden Arten sind so umgeformt, daß die Spermatozoen direkt in die Spermatheka gelangen können. Damit wird der ursprüngliche, auch für Meliponen nachgewiesene Übertragung der Spermatozoen in die Ovidukte 'überwunden'.

\section{Evolution / Paarungsverhalten / Kopula- tion / Apis}

\section{REFERENCES}

Adams J, Rothmann ED, Kerr WE, Paulino ZL (1977) Estimation of sex alleles and queen matings from diploid male frequencies in a population of Apis mellifera. Genetics 86, 583-596

Alcock J, Barrows EM, Gordh G, Hubbard LG, Kirkendall L, Pyle DW, Ponder TL, and Zalom FG (1978) The ecology and evolution of male reproductive behavior in the bees and wasps. J Linn Soc London Zool 64, 293-326

Alexander B (1991) Phylogenetic analysis of the genus Apis (Hymenoptera: Apidae). Ann Entomol Soc Am 84, 137-149

Alford DV (1975) Bumblebees Davis-Poynter Ltd, London

Anzenberger $G$ (1977) Ethological study of African carpenter bees of the genus Xylocopa (Hymenoptera, Anthophoridae). Z Tierpsychol 44, 337-374

Camargo CA de (1972) Mating of the social bee Melipona quadrifasciata under controlled conditions (Hymenoptera, Apidae). J Kans Entomol Soc 45, 520-523

Cornuet J-M, Daoudi A, Chevalet C (1986) Genetic pollution and number of matings in a black honey bee (Apis mellifera mellifera) population. Theor Appl Genet 73, 223-227

Dyer FC (1985) Mechanisms of dance orientation in the Asian honeybee Apis florea. $J$ Comp Physiol A 157, 183-198

Dyer FC (1990) Comparative analysis of the honey bee dance language: phylogeny, function, mechanism. In: "Social Insects and the Environment" IUSSI India (Veeresh GK, Mallik B, Viraktamath CA, eds) Oxford and JBH Publ Co Ltd, New Dehli, 99-100

Eickwort GC and Ginsburg HS (1980) Foraging and mating behavior in Apoidea. Ann Rev Entomol 25, 521-446

Engels W (1987) Pheromones and Reproduction in Brazilian Stingless Bees. Mem Inst Oswaldo Cruz, Rio de Janeiro 82, 35-45

Engels W (1988) Fortpflanzungsstrategien bei Bienen. Verh Dtsch Zool Ges 81,155-167

Engels E, Engels W (1988) Age-dependent queen attractiveness for drones and mating in the stingless bee, Scaptotrigona postica. $J$ Apic Res 27,3-8

Garnery L, Vautrin D, Cornuet JM, Solignac M (1991) Phylogenetic relationships in the genus Apis inferred from mitochondrial DNA sequence data. Apidologie 22, 87-92

Gary NE (1963) Observations of mating behaviour in the honeybee. J Apic Res 2, 3-13

Gary NE (1969) Mating behaviour of the honey bee. Proc Int Beekeep Congr 22, 413-414

Haas A (1949) Arttypische Flugbahnen von Hummelmännchen. $Z$ Vergl Physiol 31, 281307

Harbo JR (1971) Annotated bibliography on attempts at mating honeybees in confinement. Int Bee Res Association Bibliogr No.12, Gerrards Cross, England

Hennig W (1969) Die Stammesgeschichte der insekten. Senckenberg-Buch 49, Frankfurt a.M. (W Kramer)

Kerr WE, Zucchi R. Nakadaira JT, and Botolo JE (1962) Reproduction in the social bees. $J$ $N Y$ Entomol Soc 70, 265-276

Koeniger $G$ (1981) Entfernung des Begattungszeichens durch den sich paarenden Drohn (Apis mellifera L.). Proc Int Beekeep Congr 28, 235-237 
Koeniger G (1984) Funktionsmorphologische Befunde bei der Kopulation der Honigbiene (Apis mellifera L.). Apidologie 15, 189-204

Koeniger G (1986) Mating sign and multiple mating in the honeybee. Bee World 67, 141150

Koeniger $G$ (1988) Mating flights of honey bee drones (Apis mellifera L.) - a film documentation. In: The flying Honeybee (W Nachtigall, ed) Biona Report 6

Koeniger $G$ (1990) The role of the mating sign in honey bees, Apis mellifera L.: Does it hinder or promote multiple mating ? Anim Behav 39, 444-449

Koeniger G, Koeniger N, Fabritius M (1979) Some detailed observations of mating in the honeybee. Bee World 60, 53-57

Koeniger G, Koeniger N, Mardan M, Punchihewa RWK, Otis GW (1990) Numbers of spermatozoa in queens and drones indicate multiple mating of queens in Apis andreniformis and Apis dorsata. Apidologie 21, 281-286

Koeniger G, Koeniger N, Mardan M, Otis G, Wongsiri $S$ (1991) Comparative anatomy of male copulatory organs in the genus Apis. Apidologie 22, 539-552

Koeniger N (1976) Neue Aspekte der Phylogenie innerhalb der Gattung Apis. Apidologie 7, 357-366

Koeniger N, Koeniger G (1980) Observations and experiments on migration and dance communication of Apis dorsata in Sri Lanka. $J$ Apic Res 19, 21-34

Koeniger N, Koeniger G, Punchihewa RKW, Fabritius Mo., Fabritius Mi. (1982) Observations and dance communication in Apis florea in Sri Lanka. J Apic Res 21, 45-52

Koeniger N, Wijayagunesekara HNP (1976) Time of drone flight in the three Asiatic honeybee species (Apis cerana, Apis florea, Apis dorsata). J Apic Res 15, 67-71

Koeniger N, Koeniger G, Tingek,S, Mardan M, Rinderer TE (1988) Reproductive Isolation by different time of drones flight between Apis cerana (Fabritius, 1793) and Apis vechti (Maa, 1953). Apidologie 19, 103-106

Koeniger N, Koeniger G, Wongsiri S (1989) Mating and sperm transfer in Apis florea. Apidologie $20,413-418$
Lindauer M (1956) Über die Verständigung bei indischen Bienen. $Z$ vergl Physiol 38, 521 . 557

Michener CD (1974) The Social Behavior of the Bees. Harvard University Press, Cambridge, Mass

Punchihewa RWK, Koeniger N, Koeniger G (1990) Congrgeation of Apis cerana indica Fabricius 1798 drones in the canopy of trees in Sri Lanka. Apidologie 21, 201-208

Rinderer TE, Collins AM, Pesante D (1985) A comparison of Africanized and European drones: weights, mucus gland and seminal vesicles weights, and counts of spermatozoa. Apidologie 16, 407-412

Röseler PF (1973) Die Anzahl der Spermien im Receptaculum seminis von Hummelköniginnen (Hym., Apoidea, Bombinae). Apidologie 4, 267-274

Ruttner F (1973) Drohnen von Apis cerana auf einem Drohnensammelplatz. Apidologie 4, 41.44

Ruttner F (1975) Ein metatarsaler Haftapparat bei den Drohnen der Gattung Apis (Hymenoptera: Apidae). Entomol German 2, 22-29

Ruttner F (1988) Biogeography and Taxonomy of Honeybees. Springer Verlag Berlin

Silva DLN da, Succhi R and Kerr WE (1972) Biological and behavioural aspects of the reproduction in some species of Melipona ( $\mathrm{Hy}$ menoptera, Apidae, Meliponinae). Anim Behav 20, 123-132

Vinson SB, Franckie GW (1990) Teritorial and Mating Behavior of Xylocopa fimbriata $\mathrm{F}$ and Xylocopa gualanensis Cockerell from Costa Rica. J Ins Behav 3, 13-32

Wongsiri $S$, Limbipichai $K$, Tangkanasing $P$, Mardan $M$, Rinderer T, Sylvester HA, Koeniger G, Otis G (1990) Evidence of reproductive isolation confirms that Apis andreniformis (Smith, 1858) is a separate species from sympatric Apis florea (Fabricius, 1787). Apidologie 21,47-52

Woyke $J(1960)$ Natural and artificial insemination of queen honeybees. Pszczel Zesz Nauk 4, 183-275

Woyke $J(1975)$ Natural and artificial insemination of Apis cerana in India. J Apic Res 14, 153-159 